\title{
TARP 27-35 Peptide Vaccine
}

National Cancer Institute

\section{Source}

National Cancer Institute. TARP 27-35 Peptide Vaccine. NCI Thesaurus. Code C85462.

A peptide-based cancer vaccine, containing amino acid residues 27 through 35 of T cell receptor gamma alternate reading frame protein (TARP), with potential immunostimulatory and antineoplastic activities. Upon administration, TARP 27-35 peptide vaccine may stimulate a host cytotoxic T-cell (CTL) response ag ainst TARPexpressing tumor cells, resulting in tumor cell cytotoxicity. The nuclear protein TARP is commonly expressed on prostate and breast cancer cells and is highly immunogenic. 